\title{
Features of Establishing Accounting Policy in Tourism Enterprises
}

\section{Temirkhanova Mutabar Juraevna}

Department of Economics, Tashkent State University of Economics, Uzbekistan

*Corresponding author: Juraevna TM, Department of Economics, Tashkent State University of Economics, Uzbekistan, Tel: +9989998341786; E-mail: mutabarchik@mail.ru

Received date: February 01 2018; Accepted date: May 17, 2018; Published date: May 24, 2018

Copyright: (c) 2018 Juraevna TM. This is an open-access article distributed under the terms of the Creative Commons Attribution License, which permits unrestricted use, distribution, and reproduction in any medium, provided the original author and source are credited.

\section{Abstract}

In this article questions on improvement of accounting policy in tourist companies are disclosed. The essence of accounting policy and its need, as well as proposals on the approximation of international standards, features of the general, methodical, technical and organizational sections of accounting.

Keywords: Accounting policy; General department; Methodological aspects; Technical department; Organizational department; International standards

\section{Introduction}

The proper organization of financial and economic activities at the tourism enterprises operating in our country and the effective management of cash flows are crucial. Accounting and financial reporting is required in order to provide information about material and non-material resources for tourism. One of the first tasks in this process is the necessity and formulation of accounting policies in tourism enterprises. At present, the normative-legal or practical recommendations on the understanding of accounting policy, its necessity, essence and significance and how it can be shaped in enterprises operating in the tourism sector are insufficient.

The results of the research show that practically all tourist enterprises in the country have developed a different accounting policy. But they are not perfect, and we cannot be fully confronted with the requirements of the International Standards (ICC). Today, the sole-ofthe-counter document is the so-called "Accounting Policies, Changes in Accounting Estimates and Errors" [1].

The purpose of this IFRS is to establish criteria for the selection and modification of accounting policies and to determine the accounting policies, the adjusted accounting treatment, and the disclosure requirements for the adjusted estimates. The Standard addresses the relevance and reliability of the information reflected in the financial statements of entities, including those in the tourism industry, and is designed to enhance comparability of these financial statements between periods and other financial statements.
It should be noted that the international standard also provides general descriptions not only on formulating the accounting policy, but also reflecting data on estimated costs and errors, but this is not in our practice. Taking into account the fact that the order of computing policy in the activity of enterprises is one of the new directions in the accounting system, it is observed that the requirements for the quality and content of tourism enterprises are not sufficiently sufficient and are not structured in the conditions of modernization and diversification of the economy.

In our opinion, the accounting policy implies that timely accounting of tourism enterprises, timely identification of prime cost of services, effective management decisions, cash flows, in particular foreign exchange transactions, travel expenses and other legitimate accounts receivable and payable debts and become one of the key tools to attract and account for various investments in the industry. In Uzbekistan, the brand includes the world-famous touristic brands ("Tretyakov Gallareya" - Russia, "Welcome to Great Britain" - Britain, "España - I need Spain", Spain, "Visit Finland" - "Kiviana" New Zealand, "Lithuania - Real is beautiful" -Litva, Rio 2016- Brazil) is an important part of the development of tourism services.

\section{Literature Review}

We refer to the interpretation of our accounting policies and the methodology of the flour forming method.

Accounting policy is defined as follows: "Accounting policy" means a set of rules and methods adopted by the head of the undertaking in accordance with their principles and principles for accounting and financial reporting "[2] (Table 1).

\begin{tabular}{|l|l|l|}
\hline $\mathbf{N}$ & Scientists & Definitions \\
\hline 1 & $\begin{array}{l}\text { Prof. According } \\
\text { to Yu.ltkin }\end{array}$ & $\begin{array}{l}\text { "Accountability Policy" is a collection of accounting methods that are specifically selected for economic activity [3]. This definition is } \\
\text { generalized and does not cover all aspects of accounting policy. The reason for this is that companies choose alternative ways of choosing } \\
\text { their accounting policies. Normative documents also contain alternatives that are not available. }\end{array}$ \\
\hline 2 & $\begin{array}{l}\text { prof. } \\
\text { Jurayev's recipe } \\
\text { is very } \\
\text { reasonable: }\end{array}$ & $\begin{array}{l}\text { "Accounting policy is an accounting system that selects and publishes alternative methods and forms of accounting permitted in regulatory } \\
\text { acts regulating economic entities" [4]. }\end{array}$ \\
\hline
\end{tabular}




\begin{tabular}{|l|l|l|}
\hline 3 & $\begin{array}{l}\text { Prof. According } \\
\text { to A. lbragimov's } \\
\text { description: }\end{array}$ & $\begin{array}{l}\text { "Accountability policy is a set of accounting methods that fully comply with the economic function of a selected entity." It also says that the } \\
\text { author should not only set up an accounting policy for economic entities, but also develop an accounting policy for each sector [5]. }\end{array}$ \\
\hline 4 & $\begin{array}{l}\text { Prof. According } \\
\text { to R. Kholbekov: }\end{array}$ & $\begin{array}{l}\text { "The corporate accounting policies mean that accounting for the enterprise is based on the government's adoption of laws, regulations, and } \\
\text { decrees taking into account the specific technological features of the enterprise." Also, in his opinion, all the existing enterprises have } \\
\text { unique technological features that are different from each other. Therefore, it is crucial to examine the role, function, and specific } \\
\text { technological processes of the same company in society as it carries out its accounting policy [6]. }\end{array}$ \\
\hline 5 & $\begin{array}{l}\text { The recipes of } \\
\text { M.Tulakhodjaeva }\end{array}$ & $\begin{array}{l}\text { "Accounting policy is a set of methods used by the managing subject for accounting and maintaining financial reporting in accordance with } \\
\text { their principles and principles" [7]. }\end{array}$ \\
\hline 6 & Prof. A. Pardaev & $\begin{array}{l}\text { "Corporate accounting policy is a set of forms and methods of accounting that are important to the entity itself and are defined and } \\
\text { published on the basis of common rules" [8]. }\end{array}$ \\
\hline
\end{tabular}

Table 1: Recipients of account scholarships.

As can be seen from this, the author keeps the technological features of the enterprises in the formation of more account policies. However, it would be appropriate to take into account the fact that the accounting policy is also derived from the form of ownership and the intended purpose of enterprises.

If we take into consideration the fact that the information obtained and the financial statements made therein are comparable to some period of time, the accounting policy is not an exaggeration to achieve that objective. Raximov M by definition: Corporate identity politics this is the conclusion of the Company's accounting and financial reporting to reflect its special economic processes in accordance with the rules or determined on the valuation of property, and the summary of the report in full, which will follow the form and style [9].

In this way, the author has attempted to give a wider definition of accountability. However, these features cannot fully describe the accounting policy. That is, they did not give an idea of who would be shaped and selected by these two policies. The analysis of foreign economists' perceptions of accounting policies is as follows. In particular, the Russian scholar Rojnova OV and Grishkinalarning SN said: 'Accounting policies - within the framework of the activities of the enterprise and on the basis of generally accepted rules of doing business accounting methods and forms [10].

In addition, the Russian Federation and the Regulation on the accounting policy of 'identity' following the assessments: The word 'identity policy, accounting methods - the first observation, a measure of the value of the total in the final grouping and aggregations are understood [11].

Foreign trade regulations, including the US accounting standard related to the following: 'Accounting policies applied in the management usullarki, in certain circumstances, according to the company's financial situation, which occurred in the privacy of economic activity in conformity with the changes [12].

The international accounting standard No. 8, 'Accounting policies, changes in the calculated price, and errors in accounting policies described in the following paragraph 5: policy account is used by business entities providing financial reporting and the preparation of certain principles, methods, practices, rules and practices "[13].

Research Methodology of the research is to study the processes of economic reality in the process of scientific methods -experimental research, compilation, analysis, logical grouping and comparable methods, abstract logical thinking, prospective, comparative analysis, statistical analysis, forecasting, and other methods are used [14].

\section{Analysis and Results}

By examining and analyzing the above-mentioned definitions, it can be concluded that all aspects of accounting policy development are not fully reflected in the views. Below we will provide you with comparative information when formulating your account policy (Table 2).

\begin{tabular}{|c|c|c|c|}
\hline ISA - 8 & $R A-1 / 2008$ & NSA-1 & Invitation for Tourism \\
\hline \multicolumn{4}{|l|}{ Names } \\
\hline $\begin{array}{l}\text { Account Policies, Changes in Estimated } \\
\text { Prices and Errors }\end{array}$ & $\begin{array}{l}\text { Accounting policy in } \\
\text { organizations }\end{array}$ & Accounting policy and financial reporting & $\begin{array}{l}\text { Formation of accounting policies in } \\
\text { tourism enterprises }\end{array}$ \\
\hline \multicolumn{4}{|l|}{ Structure : } \\
\hline $\begin{array}{l}\text { Purpose, scope, definitions, accounting } \\
\text { policies, changes in accounting policy, } \\
\text { consistency, errors, expiration date }\end{array}$ & $\begin{array}{l}\text { Common rules, accounting } \\
\text { policies, account policy } \\
\text { changes and accountability } \\
\text { policies }\end{array}$ & $\begin{array}{l}\text { General rules, standard purpose, scope of } \\
\text { application. Explained the composition of the } \\
\text { financial statements, the main principles, the } \\
\text { accounting policies }\end{array}$ & $\begin{array}{l}\text { General department, } \\
\text { methodological department, textile } \\
\text { department and organizational } \\
\text { department }\end{array}$ \\
\hline
\end{tabular}

Table 2: Comparative information about the composition of the account policy.

Based on the above considerations, the concept of an enterprise's accounting policy can be summarized as follows: "Accounting policy is a set of acceptable methods and rules adopted by the head of the business entity on the basis of alternative accounting and financial reporting principles". 
Page 3 of 4

Thus, the obligation to form an accounting policy and the responsibility for organizing the bookkeeping are directly entrusted to the head of the enterprise.

Therefore, we believe that the modern leader has a good understanding of these issues and understands that the chief accountant grants the right to reflect only certain transactions that are properly documented.

In our opinion, it is expedient to formulate tourism business in tourism enterprises, particularly in the research object ENJOY TRAVEL, with the following three divisions:

Firstly, to indicate the cases, which reflect the selected methods of recognition, measurement and reflection of the objects of accounting, to describe methodological aspects on each item of balance and other forms of the report;

Secondly, the accounting technique, including the plan of work necessary for the accounting, the binding of the account registers, the timing and order of the document forms, inventory, the modern computers and other organizational techniques, the classifiers and codifices necessary for their application;

Thirdly, the organization of bookkeeping, the selected organizational form of accounting, the method of organizing the work of accountants, the choice of the distribution of functional obligations between accountants, the organization of the documents circulation, the appointment of the chief accountant, the rights and obligations.

In shaping the accounting policies of tourism businesses, the focus should be on its methodological aspects. Studies show that, in practice, tourism companies have limited accountability policies, with more explicit reporting of the National Accounting Standard $\mathrm{N} 1$ "Accounting Policies and Financial reporting" for the accounting objects. Taking this into account, we have proposed a general framework that is to be reflected in the accounting policies for the resident enterprises (Table 3).

\begin{tabular}{|l|l|}
\hline Section Name & Structure \\
\hline General & The legal framework and principles of accounting policy are reflected \\
\hline Methodical section & $\begin{array}{l}\text { The procedure of recognizing, evaluating, calculating selected methods of accounting, accounting for amortization will be reflected in } \\
\text { accounting objects (long-term assets, current assets, equity and liabilities). }\end{array}$ \\
\hline Technical department & $\begin{array}{l}\text { Tourist companies are provided with document circulation, accounting registrars and their maintenance, accounting for economic } \\
\text { operations, record keeping records, forms of documents, inventory, procedures for posting on modern computers. }\end{array}$ \\
\hline Organizational unit & $\begin{array}{l}\text { Qualification requirements, duties, rights and responsibilities of the chief accountant in the field of tourism. The accounting apparatus and } \\
\text { its function and structure are discussed. }\end{array}$ \\
\hline
\end{tabular}

Table 3: The structure of accounting policies in travel companies (offer).

According to the general aspects of the accounting policy, each tourism company develops and approves its accounting policies with regard to its financial and economic activities.
It is expedient for the accounting entities to cover the following types of accounting in forming accounting policies at enterprises engaged in tourism activities (Table 4).

\begin{tabular}{|c|c|c|}
\hline $\mathbf{N}$ & Name of object & Objects in the subject \\
\hline 1 & For long-term assets: & $\begin{array}{l}\text { Basic tools } \\
\text { Intangible assets } \\
\text { Investments } \\
\text { Capital investments }\end{array}$ \\
\hline 2 & For current assets: & $\begin{array}{l}\text { Brand Material Reserves } \\
\text { Money resources } \\
\text { Debtor debts }\end{array}$ \\
\hline 3 & On Private Equity: & $\begin{array}{l}\text { Charter capital } \\
\text { Added capital } \\
\text { Reserve capital } \\
\text { Undistributed Profit (Loss) }\end{array}$ \\
\hline 4 & Long and short term liabilities: & $\begin{array}{l}\text { Charter capital } \\
\text { Added capital } \\
\text { Reserve capital } \\
\text { Undistributed Profit (Loss)... } \\
\text { Bank loans } \\
\text { Other payables }\end{array}$ \\
\hline
\end{tabular}


Citation: Juraevna TM (2018) Features of Establishing Accounting Policy in Tourism Enterprises. Bus Eco J 9: 353 . doi: $10.4172 / 2151-6219.1000353$

Page 4 of 4

\begin{tabular}{|c|c|c|}
\hline 5 & Income: & $\begin{array}{l}\text { Income from core operations } \\
\text { Income from financial activity } \\
\text { Income from investment activity }\end{array}$ \\
\hline 6 & Expenses: & $\begin{array}{l}\text { The cost of rendered services } \\
\text { Period expenses } \\
\text { Financial activity costs }\end{array}$ \\
\hline
\end{tabular}

Table 4: Objects of accounting that should be reflected in the accounting policies of tourism companies.

\section{Conclusion}

As a result of the research, the following conclusions were made:

First of all, the information obtained from the creation and analysis of accounting balances in tourism enterprises and firms, which are the object of research, provides important information on the financial status and liquidity of the company for the users. The importance of balance reflects the best financial information system that evaluates the firm's financial position. Its usefulness is that the balance is an important source for most financial ratios, including liquidity, financial flexibility, profitability, and valuation of its assets;

Second, the name of the bookkeeping balance in International Standards (IFRS 1) today is called a "Financial Statement" with a broader definition. In our opinion, it is desirable to rename the accounting balance sheet in the tourist business with the term above.

This creates a basis for attraction of external investments for tourist enterprises, further increase of confidence in enterprises and allows to approach the IFRS. In accordance with the "Financial reporting" (the "Accounting Balance"), the following requirements shall be met:

- Condition of net assets of the enterprises; the size of the tourist enterprise profit compared to the period;

- Tax liability paid by taxpayers;

- Business status and future of business enterprises.

Thirdly, financial results are a set of related economic indicators, which are determined by comparing income and expenses of tourist enterprises. The financial result should be interpreted as an economic indicator in profit, loss, profit or loss resulting from the operation of the enterprise, based on a specific sequence in its accounting and analysis. This sequence will depend on the purpose of determining the financial results and the accounting for which the procedures are set.

The traditional form of determining the financial results of tourist companies is determined by the following formula:
Profit (loss)=income - expense

In our opinion, the final financial result for this formula does not provide sufficient information for company managers, founders, financial management, analysts and other stakeholders. Therefore, persons interested in determining their financial result may determine their policies. Tourist companies today consider their financial results mainly based on tax legislation and international and national accounting standards.

\section{References}

1. IFRS (2017) Accounting Policies, Changes in Accounting Estimates and Errors.

2. National accounting standards of the Republic of Uzbekistan (NSBU) No: 1. Accounting policy and financial reporting.

3. Yu M (2001) Accounting policy in Uzbekistan. Publishing center assosiation of auditors and accounter of Uzbekistan, pp: 6-7.

4. Jo'raev N (1998) Accountancy policy of the company, pp: 49-50.

5. Ibragimov A (2008) Financial and management accounting. Educational manual.

6. Kholbekov R (2012) Accounting theory. Educational manual.

7. Tulakhodjaeva MM (2001) Financial accounting.

8. Pardaev AX (2002) Management Accounting.

9. Rakhimov M (1999) Improving accounting, analysis and audits of financial results in grain production enterprises in market economy: abstract.

10. Rojnova OV, Grishkina SN (2001) Accounting policy: forming, showing.

11. Accounting policy. Rule of MF of the Russia. Obstrojstvenniy polojeniy po buxgalterskomu uchetu.

12. Accounting Policies.

13. Generally Accepted Accounting Principles, Other Comprehensive Basis of Accounting, IFRS.

14. IAS 8 - Accounting Policies, Changes in Accounting Estimates and Errors. 